\title{
19. Matai Titles and Modern Corruption in Samoa: Costs, expectations and consequences for families and society
}

\section{A. Morgan Tuimaleali'ifano}

On a bright October Saturday morning in 2005, I could make out his outline in front of the R. C. Manubhai hardware store in Raiwaqa, Suva. Desmond Dutta was a Fiji-born Samoan who had left Fiji almost 20 years ago. His father was an Indo-Fijian and his mother a Samoan of Chinese ancestry. We first met in Fiji in the mid-1980s while I was doing fieldwork in Fiji's minority communities. Proud of his Samoan heritage, Dutta frequently discussed with me his desire to retrace his mother's family. ${ }^{1}$ These topics were the focus of our regular Friday afternoon discussions at the Suva market where he earned a living selling the popular cumquat fruit juice. Soon after Fiji's two coups in 1987, Dutta made good his word and left Fiji for Samoa.

When he returned to Fiji, he appeared fragile, ageing prematurely, his body bent and face drawn with signs of affliction by diabetes. But now he was looking forward to returning to Samoa again. 'Our side of the 'aiga has just won a major court case over the [Manuleleua] family title. It took us six years to fight this case, and lots of money went into it. Boy, I took a lot of hammering. But, the title has finally returned to the right side of the family.'

'What do you mean by hammering?' I asked.

'During the court case, the other family parties called me by all sorts of names. Fai mai o a'u o le Fiki. Ga lau lo'u Igikia. Fai mai o a'u o le Saiga oga o le kiga o le Saiga. Fai mai o a'u o le Fiki ua sau fia pule i le aiga. [They called me an Igikia (Indian), a Saiga (Chinese) because my mother is Chinese and they said that I was a Fijian who was coming to take over the family.] It was very painful. But you know what our fa'a Samoa is like, eh? That is part of our culture. One minute we're stabbing each other and the next we're crying and making the loku [church] to forgive each other. And we forget everything that was thrown at each [other] until the next court case. Oh, I tell you, our fa'a Samoa, it's funny, eh?' We both laughed knowingly and then parted. Dutta had not only retraced his roots but was revelling in the consequences of that knowledge.

Modern Samoa is a nation that is a product of all the forces of globalisation. The legacy of the wave emanating from the west 3,000 to 3,500 years ago is apparent in the way the island nation is governed largely through family and village titles. As ancestral names, titles are passed down in families and are ceremonially 
conferred on chosen individuals who then represent the family in public life. Without a title, an individual has no right to speak in family and village councils. A title secures membership and rights within a family to land and common village property. Conferral ceremonies can range from elaborate gift exchanges for high titles to tea parties for minor ones. The normal practice is for the family to consult the village council on a date for their candidate's installation in a saofa'iga (an installation ceremony) and thereupon, formal admission into the village council. Titles are also significant because, as the sole decision-makers in the village, councillors collectively control about 80 per cent of the land. ${ }^{2}$ From the West, the second wave, beginning in 1492 and finally reaching Samoa in the 19th century, introduced the apparatus of a modern state. When titles are disputed, virtually every development effort under the state apparatus is threatened, including land rights, homes and livelihoods. There is little incentive to develop. Under the laws of the first wave of colonisers, when families could not agree, war decided the disputes, but wars had a habit of lingering. These forms of conflict resolution and settlement were inefficient and disruptive to second-wave settlers and eventually led to colonial takeover.

When Germany took over in 1900, the German Administration effectively circumvented local conflicts by establishing a Land and Titles Commission (later a court) to arbitrate disputes. It did not stop the conflicts, but it stopped the wars. The Germans managed to successfully channel local disputes through the court system. Since independence in 1962, title disputes have become so numerous that resolution of conflict can take years. And this is what I would like to consider. In Samoa, as elsewhere in the Pacific, the problem of resource ownership such as land is tied inextricably to family titles. In Fiji, the land issue is tied to leases controlled by the Native Land Trust Board, and the relationship between it and the landowner and tenants. In Samoa, when families are locked into a title succession dispute as they often are, production invariably is restricted. ${ }^{3}$

How are these titles appointed and their titleholders installed, and what are the consequences for the social and state apparatus? What is the place of cash in the title-installation process? Is cash, much of it generated in the global economy beyond Samoa's shores, corrupting that process? More broadly, in what ways is Samoan tradition adapting to and being corrupted by the forces of globalisation?

My case study is the Samoan village of Salelologa, on the island of Savai'i, fabled home of Hawaiki. In early 2001, my mother's 64-year-old cousin and holder of the Luamanuvae title, Kirika Fiso, approached me with his wish to install new family titleholders, including one of my mother's children. Appointed in 1970 as a co-titleholder, Fiso had outlived many of his peers, and had held the senior elder position in the Sa Luamanuvae clan of the Li'aga branch for some time. 
Though many appointments had been made, many titleholders chose to live outside the village. The title Luamanuvae was one of two titular titles of Salelologa village. ${ }^{4}$ Like many of his generation, Fiso had moved between subsistence and the cash economy having been a clerical officer with various merchandising companies and government departments. He had also served in managerial positions with the Congregational Christian Church in Samoa and overseas and with the Seventh-Day Adventists. In inviting us to assume the title, he made it clear that he could not guarantee another opportunity during this lifetime. When he finished his story, I thanked him and accepted the offer, and told him that it was largely out of respect for the memory of my mother's longstanding desire to honour her ancestors. During her lifetime, her children were all young and more immediate needs assumed higher priority.

Fiso had an ulterior motive, which he hinted at but which I did not comprehend fully until after the installation. In the mid-1980s, Salelologa, Tafua and Fa'ala, located along the south-eastern coast of Savai'i, entered into an agreement with a Swedish environmental NGO in which the villages were to be paid several thousand dollars in aid not to develop or log their land for at least 50 years, and to use the forest only for customary uses, e.g. the occasional harvesting of timber for local needs and of plants for medicines. The arrangement worked well with regular payments and minimal pressure on the land. But after most of the money had been paid, in 1999, the Salelologa Council was induced by the Tofilau Eti Alesana-led HRPP government to sell 1,162 hectares of its conserved rainforest land for a politically motivated township scheme. The council saw nothing wrong with selling the land it had already agreed and been paid to preserve. In early 2002, the government paid \$4 million to Salelologa. Instead of using some of this money to repay the Swedish NGO for violating the agreement, the village council was instead incensed at the NGO for not paying the final 10 per cent instalment of the money due! ${ }^{6}$ After the $\$ 4$ million was paid, another faction of the Salelologa Council, led by Pauli Elisara, petitioned the Supreme Court, claiming that they should have been paid $\$ 45$ million based on 'unfair evaluation' by the government valuer. ${ }^{7}$ This case continues with many senior matai creating new titleholders in a bid to cash in on the likelihood of more handouts.

My family's acceptance of the title implied expenses for the ceremonial gifting. The next question for the installation was costs: Fiso said the total outlay would be $\$ 35,000$. In order to defray the costs, there would be six to seven titleholders, thus reducing the individual outlay to about $\$ 5,000$ a person.

\section{Who gave what and where did it come from?}

On the evening before the title installation, the extended family and their candidates met to take stock of their contributions. Immediately, a problem 
arose. Two of the seven expected candidates failed to attend and that meant the five candidates had to come up with an additional $\$ 2,000$ to meet the $\$ 35,000$ outlay. This was clearly impossible with less than 12 hours left before installation. Who were the five candidates and what were their contributions?

1. Tovia, son of late Luamanuvae Lokeni and Poufitu; 40 years old; a gas stove manufacturing company employee in Mangere, South Auckland, New Zealand: $\$ 5,000$, seven cartons of mackerels and 11 large fine mats.

2. Mokeni (Morgan), son of Ta'alefili, the granddaughter of Luamanuvae Pae'e; 47; university lecturer, Fiji: $\$ 3,500$, two cartons of chickens and six fine mats.

3. Tofu, son of Tia'itupe Luamanuvae Tofu and Leatigaga Fa'aafu of Lauli'i village, 'Upolu; 34; Apia-based employee (after the installation, he and his young family migrated to live in Salelologa in February 2002): \$3,000, five 'ie toga, seven cartons of mackerels and five large fine mats.

4. Punivalu, son of Luamanuvae Pule; 43; a village farmer from Fatusi, Savai'i: $\$ 3,000,10$ large fine mats.

5. Keli, grandson of Luamanuvae Tofu; 64; casual worker for the Electricity Power Corporation and the only candidate who was a permanent resident of Salelologa. He donated $\$ 1,000$ consisting of $\$ 300$ cash and $\$ 700$ worth of groceries, five cartons of mackerels and five large fine mats. He had also undertaken extensive repairs to the family house in which the installation ceremony was conducted.

At the meeting, an elderly female family member, Mateai, attended and contributed \$280. Mateai and her son, Fonoia, lived one kilometre away and were gifted $\$ 20$ for the bus fare and were driven home. The total amount collected was $\$ 15,780,19$ cartons of mackerels ${ }^{8}$ and two cartons of chicken. ${ }^{9}$ Although the 38 fine mats were considered a small number, they were all high-grade mats, as attested by those present. The immediate problem was the cash. Though short by $\$ 20,000$, it covered the cash payments and fine mats for religious ministers, the speech-maker, clan heads, and lesser titleholders in attendance at the 'ava ceremony, who received less than at previous installations.

\section{Where did this cash come from?}

It was considered bad taste to seek details of sources of income from the other four co-titleholders, and this paper is limited to my own sources. In Suva, my wife and I took the view, one common to many, that since I was the recipient, we should take the initiative and provide at least half the cash. As we did not have spare cash, we raised funds by selling umu packs, organising cake drives, and making monthly cash deductions from salary and allowances. Our Suva umu packs were sold for $\$ 20$ each (two luau, one taro, one bowl of raw fish, one No. 12 chicken, and a bowl of fruit salad). Our dollar target was $\$ 4,000$, with the 
expectation that my siblings would make up the $\$ 1,000$ balance. Despite our ambitious plans, our efforts raised the modest sum of $\$ 700$, barely enough for one return airfare. In the end, the bulk of the money came from two sisters and a brother living in the USA, ${ }^{10}$ two of whom were awaiting Green Cards from the Department of Immigration and Naturalization Services. What were their sources of livelihood? My oldest sister worked as a primary schoolteacher and the other worked at a pharmaceutical plant and was studying part-time. My 39-year-old brother had only recently begun working as a part-time primary schoolteacher after being an unpaid volunteer for almost 10 years. They contributed $\$ 3,000$. The only one who could travel from the USA, my oldest sister, attended the installation at her own expense and bought more food. In addition to her airfare, she paid $\$ 1,000$ for hotel accommodation and a rental car, and another $\$ 100$ contribution to the first Sunday to'ona' $i$, a lunch following the installation. In addition, my three siblings contributed to other installations. One thousand tala $(\$ 1,000)$ was given to another sister's husband whose uncle was installed in Satupa'itea, 11 \$2,000 for a New Zealand-based brother, a recipient of two titles, 12 and $\$ 2,000$ for a Samoan-based brother for taking a title from Iva village. ${ }^{13}$ At the last moment, more titles were on offer for cash, and for another $\$ 1,000$, my oldest sister was persuaded to take one from the same village. ${ }^{14}$ The total amount for installations came to $\$ 8,500$ (about $\$ A 4,000$ ), in addition to about $\$ 100$ customary contributions for each new titleholder for the Sunday lunches. Almost all of this money was derived from the modest wages of primary schoolteachers and factory workers.

\section{The installation ceremony and the political agenda}

At installation ceremonies, there are two main events. After the introduction and exchange of pleasantries and collection of 'ava stems from the assembled matais, the first major item is the fa'atau - the selection of the speech-maker through an open contest among the orators. The second is the lauga - the act of making the speech, during which reference is made to the genealogy of the title and the title is situated within existing village and district hierarchies. When strong and powerful speakers take the stage, the contest is the most thrilling part of the ceremony, with seasoned orators eager to display their political wares. The contest provides a window of opportunity for newly installed titleholders to witness first hand the power structure and those behind it. The higher the title, the higher the rewards are likely to be.

Salelologa, like most other villages, operates under a dual system of authority exercised by titular family heads and orator clan heads, in oppositional relationship to each other. While the two titular titles stand at the apex of the hierarchy, their power is largely ceremonial. Effective power is wielded by two bands of orators, the falefia and falesalafai, numbering seven clans. ${ }^{15}$ In the speech contest, everyone waited expectantly for the customary rivalry between 
the two groups. Pipi Lavilavi, the head of the Pipi clan and leader of the falefia on that day, initiated the contest. He began by acknowledging clan heads and stated firmly and clearly his wish to speak on behalf of their band, and each clan head of the falefia conceded their right in favour of him. Pipi then turned to the three clan heads of the falesalafai and repeated his wish. The head of the Seumanu clan, Seumanu Tupea, responded on their behalf and obtained Pipi's concurrence to allow their band to negotiate a consensus. After about 30 minutes of protracted negotiations with the falefasalafi, Seumanu obtained their vote to represent them against the falefia. Seumanu then turned to Pipi and thus began a two-way contest.

For the next 45 minutes, the two clan heads dug deep into their political repertoire of emotional blackmail and vanity, to outmanoeuvre the other. Both stood their ground and there was considerable entertainment value as they parleyed and toyed with each other's apparent foibles. Those new to the contest feared physical violence. ${ }^{16}$ In the contest, the two men showed no sign of yielding and eventually Pipi resorted to higher authority. In front of a captive audience, he told Seumanu that their absent leader, Matamua (Pua'atoga), on account of ill health, had appointed him as his representative. Pipi explained that before the installation, the falefia had assembled at Matamua's residence and waited for the falesalafai. When the latter failed to attend this preliminary meeting, Matamua extended his blessing and anointed Pipi as spokesperson. As proof, Pipi lifted Matamua's flywhisk as the badge of office. Seumanu at this point became visibly angry and reaffirmed his allegiance to Matamua as leader and, in regretful tones, turned to his falesalafai colleagues and asked them to accept Pipi as their spokesman. Pipi returned the compliments and proceeded with his speech, first acknowledging the assembled dignatories, then outlining the procedure for 'ava distribution and enunciating the family genealogy. Before he could continue with the genealogy, he was stopped by the head of the Muagututi'a clan, Muagututi'a Ami, who politely interjected and asked Pipi to skip this aspect, and beckoned him to go straight to the blessing of the titleholders and distribution of 'ava. Pipi concurred and, as he concluded his speech, the master of the 'ava ceremony, from the back of the house, began the chant and enunciated each titleholder's 'ava cup title. It began with the new titleholders followed by the clan heads according to a predetermined order of precedence, with the older peers first.

As the clan heads received their 'ava cup, each took the opportunity to give words of advice to the new titleholders. In wishing them well, they also emphasised the importance of commitment to family, the village council (by implication, its constituent women, and non-titled men and women elements), the church and the government, in that order. They spoke of the customary relationship between the orator groups and the titular clans as represented by senior holders of Muagututi'a and Luamanuvae titles. Others emphasised the 
courtesies expected of us as younger and newer titleholders towards older and more senior titleholders. Others were more blunt in their expectations as graphically illustrated by the head of Fiu Loimata II, representing the Fiu clan. A former member of parliament and a forceful speaker, his advice was a stinging reminder of the paradoxical relationship between titular and orator chiefs. Pointing to senior Luamanuvae and Muagututi'a titleholders sitting at the opposite end of the house, Fiu spelt out to us the relationship in dollar terms. He said, 'E uma le ola o kama la ia makou. O le lakou masagi a fekaui ma I makou i le makeki, e ke'i a ua fai mai, ku'u aku le selau kala I lau kaga. Pe o'o i se isi kaeao, fagu fagu mai, kago mai I lau afe kala lea e ku'u I lau kaga'. (The lives of those men [pointing to senior Luamanuvae and Muagututi'a] end with us. They make it their habit, whenever we meet, to give us money. They will say to us, 'Here, take this $\$ 200$ and put it in your pocket.' Or early one morning, they would wake us up and say, 'Here, take this $\$ 1,000$ and put it in your pocket.' $)^{17}$

In other words, it was his view that the orators' role was to support and speak on behalf of titular titleholders and it was the role of the titular titleholder to pay the orators, which in Fiu's terms was best done not by fine mats and pigs but in cash.

\section{The gifting}

Although I had been to other title installation ceremonies, the Salelologa ceremony was different. The one-way gifting without immediate return was of serious concern. Moreover, nothing had prepared me for what was to happen that day. I would not have believed the shameless public demands if I had not seen them myself. After the speech and drinking of 'ava, the assembly of clan heads moved to the open space outside for refreshments and in anticipation of receiving customary gifts. The sponsors also moved outside ready to distribute what had been planned the night before. As they received their gifts of cash and fine mats, some orators shamelessly demanded more and publicly stated, 'Fa'aatoa mai le fia ... tala o la'u lafo' (Give me some more dollars to make up the rest of my entitlement.) One threatened to recommend deregistering the newly installed titleholders. When our party, the sponsoring party, tried to appease them, some begrudgingly sat down only after being promised more cash.

Pipi Lavilavi, the speaker at the ceremony, as expected, got the lion's share. But having receiving $\$ 1,000$ in cash plus the largest and choicest fine mats, he then made an extraordinary plea on behalf of the 70-year-old sickly and absent Matamua Pua'atoga. In the lead-up to the gifting, it was expected that whatever gifts the speaker received would be shared with the absent orator. Instead, Pipi demanded a similar donation be given on the basis that the absent orator was sickly and might not live to see another installation. In other words, so it seemed, 
we were asked, on behalf of the village, to provide a parting gift. The stunned sponsors took a full minute to recover and renegotiate amid muffled terse epithets.

\section{Seeds of corruption}

These gifting events have a life of their own and have significant consequences. As remembered events, they are transmitted and re-lived at the next crisis such as a title installation or funeral. If the payback is not matched or bettered, the sponsoring family is stigmatised. The consequences are transmitted to a future generation of matai titleholders and their families. As opportunity arises, they will demand no less than what was demanded of them as their 'just due'.

When expectations of titleholders and families are not matched by return gifts, conflict is apt to spiral into other arenas, including places of employment, churches and schools as part of loyalty to family and village. Customary gifts derived from a subsistence economy are less likely, these days, to satisfy the needs of a family and clan structure accustomed to cash and remittances. While there is always money, there are not enough fine mats, pigs and foodstuffs. ${ }^{18}$ When food was gifted instead of cash, tropical climatic conditions required efficient redistribution. But when cash infiltrates gifting whether in the form of remittances or otherwise, redistribution it not required and gifting is taken out of the public into the private and individualised arena. As reciprocal exchanges increasingly take the form of cash payments, they enter a world of capitalism never intended for this type of family-oriented activity. In the past, installations encouraged family gatherings and redistribution of gifts. The cash installation in Salelologa did not elicit redistribution of any sort among the candidates and their families. They dispersed knowing they had debts to return to and there was little else to discuss or take home to celebrate. It seemed, at least for those remaining behind, that the focus was on payback at the next life crisis.

\section{References}

Laura, P. 2002. Family DVDs of Saofa'is in Foua, Salelologa, Samoa. Copy with author.

Methodist Board of Trustees. 1985. Ole Tusi Fa'alupega o Samoa Atoa. Compiled by the Tusi Fa'alupega Committee. Apia: Methodist Printing Press.

O'Meara, T. 1987. 'Customary Individualism.' In R. G. Crocombe (ed.), Land Tenure in the Pacific, Suva: Institute of Pacific Studies, USP.

Tuimaleali'ifano, A. M. 2006. O Tama a 'Aiga: The Politics of Succession to Samoa's Paramount Titles. Suva: USP.

Tuimaleali'ifano, M. 1990. Samoans in Fiji: Migration, Identity and Communication. Institute of Pacific Studies, Fiji, Tonga and Western Samoa Extension Centres, USP, Star Printery. 


\section{Whistler, W. A. 2002. The Samoan Rainforest, A Guide to the Vegetation of the Samoan Archipelago. Honolulu, Hawai'i: Isle Botanica.}

\section{ENDNOTES}

${ }^{1}$ His mother, Mali Dutta, is a descendant of the Manuleleua family clan, titular orator of Vaimoso village. See A. M. Tuimaleali'ifano, 1990, Samoans in Fiji, pp. 45-6.

2 The balance comprises 16 per cent government land and 4 per cent freehold. This control, it has been argued, is more theoretical than actual, and much Samoan land is de facto under individual tenure.

3 A. M. Tuimaleali'ifano, in press, O Tama a ' iga: The Politics of Succession to Samoa's Paramount Titles, USP.

4 The other was Muagututi'a. See Board of Trustees of the Methodist Church in Samoa, 1985, O le Tusi Fa'alupega o Samoa Atoa, Malua Printing Press, pp. 142-5. The Sa Luamanuvae clan is split in two branches, Pouseilala and Li'aga, each with sub-branches.

5 The late Prime Minister, Tofilau Eti Alesana, had earlier represented Fa'asaleleaga No. 1 in which Salelologa was included under his tenure of the Luamanuvae title. His Luamanuvae connection was to the Pouseilala branch.

6 See W. Arthur Whistler, 2002, The Samoan Rainforest, A Guide to the Vegetation of the Samoan Archipelago, Honolulu: Isle Botanica, pp. 150-1. Similar compromises are also appearing in Fa'ala.

7 'Salelologa wants \$45m', Samoa Observer, December 12, 2002.

8 A carton of mackerel retailed at $\$ 71$ and a carton of chicken for $\$ 81$.

9 In addition to the Luamanuvae title, the Le Atigaga title was also on offer for \$400-500.

10 Pinelo Laura (45), Suatipatipa Tuimaleali'ifano (39) and Vaivase Maualaivao (37).

11 Falani and Vaosa Asiata for the Gasu title.

12 Wellington Fiso for Le Atigaga in Salelologa and Fiso in Vaito'omuli, Palauli.

13 Lilomaiava Rev. Nerony Fiapia Tuimaleali'ifano for the Tofilau title in Iva village.

14 Laura was conferred as the Tagaloasa orator title at the same ceremony in Iva.

15 Falefia aka To'afia and comprises the titles Taotua (represented by Ioane), Pipi (represented by Lavilavi), Matamua (unidentified), and Fonoia (absent). Falesalafai comprises Seumanu (represented by Tupea), Pauli (represented by Afele) and Fiu (represented by Loimata II). See Board of Trustees of the Methodist Church in Samoa, 1985, O le Tusi Fa'alupega o Samoa Atoa, Malua Printing Press, p. 142.

16 I was later informed of earlier contests between Seumanu Tupea and Matamua Pua'atoga, the head of the Matamua clan and highest-ranking orator. At an earlier contest, the rivalry over the speech led to physical blows. The two elders rolled about the centre of the house hurling abuse at each. It ended as both quickly ran out of breath. No one lifted a finger to stop them. Scores were settled for the time being until the next round of saofa'i.

17 From DVDs of the ceremony.

18 I am grateful for Dr William Clarke's interest in and pertinent comments on this paper on October $28,2005$. 